\title{
“Peak to Leak" Pathophysiology of Burns
}

\author{
Vinayak Chavan and Ravi Kumar Chittoria* \\ Department of Plastic Surgery, Jawaharlal Institute of Postgraduate Medical Education and Research, India
}

Submission: March 07, 2018; Published: March 27, 2018

*Corresponding author: Ravi Kumar Chittoria, Department of Plastic Surgery, Jawaharlal Institute of Postgraduate Medical Education and Research, Pondicherry, India, Tel: +91-9442285670; Email: drchittoria@yahoo.com

\section{Editorial}

Burns is an emergency condition which every clinician comes across on day to day practice and understanding pathophysiology of it will help in better patient care. Endothelium acts as a permeable barrier between blood and underlying tissue, thermal burn injury not only cause direct protein coagulation but promotes endothelial dysfunction by release of proinflammatory mediators like reactive oxygen species, cytokines (platelet activating factor, tumor necrosis factor, etc.), and other

inflammatory mediators (histamine, bradykinin, etc.) from injured cells and activated neutrophils which causes increase in migration of macromolecules and fluid from the vessel into the local injured tissue, they also affect vascular permeability in distant nonburn tissue and organs through circulation of blood $[1,2]$. This important phenomenon we would like to simplify by "PEAK to LEAK" concept which is post burn injury peak of proinflammatory mediators leading to leak of macromolecules and fluid into the interstitial compartment.

\section{References}

1. Demling RH (2005) The burn edema process: current concepts. J Burn Care Rehabil 26(3): 207-227.

2. Mehta D, Malik AB (2006) Signaling mechanisms regulating endothelial permeability. Physiol Rev 86(1): 279-367.

Your next submission with Juniper Publishers will reach you the below assets

- Quality Editorial service

- Swift Peer Review

- Reprints availability

- E-prints Service

- Manuscript Podcast for convenient understanding

- Global attainment for your research

- Manuscript accessibility in different formats

( Pdf, E-pub, Full Text, Audio)

- Unceasing customer service

Track the below URL for one-step submission https://juniperpublishers.com/online-submission.php 